\title{
Le Corbusier's Modulor: Anthropometric Myth
}

\author{
Julio Lorenzo-Palomera, Carlos Fuentes-Pérez ${ }^{*}$, Yolanda Aranda-Jiménez \\ Faculty of Architecture, Design and Urbanism, Autonomous University of Tamaulipas, Tamaulipas, México
}

Received October 12, 2021; Revised November 23, 2021; Accepted December 22, 2021

\section{Cite This Paper in the following Citation Styles}

(a): [1] Julio Lorenzo-Palomera, Carlos Fuentes-Pérez, Yolanda Aranda-Jiménez , "Le Corbusier's Modulor: Anthropometric Myth," Civil Engineering and Architecture, Vol. 10, No. 1, pp. 112 - 120, 2022. DOI: 10.13189/cea.2022.100110.

(b): Julio Lorenzo-Palomera, Carlos Fuentes-Pérez, Yolanda Aranda-Jiménez (2022). Le Corbusier's Modulor: Anthropometric Myth. Civil Engineering and Architecture, 10(1), 112 - 120. DOI: 10.13189/cea.2022.100110.

Copyright $@ 2022$ by authors, all rights reserved. Authors agree that this article remains permanently open access under the terms of the Creative Commons Attribution License 4.0 International License

\begin{abstract}
Since its two publications, 1948 and 1953, the Modulor has been incorporated as an anthropometric and human proportion reference until today as part of the design process heritage. Therefore, reliable metric information sources are needed, real data-based, useful in the architectural design process. Using documentary research, this critical essay deconstructs Modulor's attributes as a reference to the human scale, as it is based on a fanciful abstract drawing but not on real population stature measurements. Le Corbusier sought to justify the 2.20 meters height fitting to the human scale only considering an arm raised humanoid figure. Anthropometric databases are used from different sources, some French, where wide samplings indicate that height measurements considered by Le Corbusier's advisers, 1.75 and 1.83, do not correspond to population mean stature, 1.60-1.69, when the Modulor was made up. It was considered, in France, from the beginning of the physical anthropology of which anthropometry is a part, 18th century, until the trends of the 20th century. In addition, data from other countries during the 19th and 20th centuries also has through Le Corbusier's lifespan. Human height is a variable measure, not standard. People can be 2.00 tall (Netherlands, 1996) or small, 1.49 (Guatemala, 1996). Neither the standing nor the seated body width was studied anthropometrically at all. Modulor besides is an excluding metric model in gender and ages. No more databases were analyzed, but those studies offer enough contrast between the abstract (Modulor) and the concrete (real people) height measurements. A large sample design, based on mean measure, is an erroneous criterion because it applies only to a population's small range. That is what Le Corbusier established with the Modulor to be the measure of all things but with fixed standard. Therefore, it is recommended to
\end{abstract}

check other sources to corroborate it. The Modulor is a myth, so it is recommended to stop including it like a database or an anthropometric manual. As a human-scale option, it might be helpful for design learning as an incorrect criteria example.

Keywords Le Corbusier, Modulor, Myth, Stature, Anthropometry

\section{Introduction}

During the architectural space design process, fitting on a human scale is necessary for inhabitants' comfort. The anthropometric references related to the design must be part of the designer's heritage in order to use the pertinent ones for each case. However, measurements of the inhabitants are not always taken to personalize the spaces, but applicable anthropometric databases are used.

There are a variety of information sources, for example, based on large samples with different people [1-7]. In addition, traditional modular proportion systems such as Shaku in Japan [8], and Canamayte in Mexico and Central America [9]. Others are based on a single figure and proportional relationships with their segments (Vitruvio, Leonardo da Vinci). And the Modulor, a humanoid fantasy based.

Charles-Édouard Jeanneret-Gris (1887-1965), self-appointed as Le Corbusier, is a representative of the Modern Movement in Architecture. His work distributed in various countries has been valued as a World Heritage [10].

Le Corbusier is an architecture referrer, the Modulor the dimensional expression was described in two books 
published for the first time in 1948 and 1953. The adventure to establish the measure of all things led the author to a dimensional play, with approximations relating golden section segments with an abstract representation of human scale with arm raised. He intended to give proportional measurements to architecture, machinery, and objects, all over the world.

Although it is still considered along with historical figures such as Vitruvius and Leonardo Da Vinci among others, as the foundation of human proportions and scale, observations have also been made that question its validity.

In the Modulor, the virtual subject image fit into the measurements grid made from that Le Corbusier invents, but it is not ergonomic [11]. The Modulor development presents confusing drawings and notes, demonstrating ignorance of real human proportions [12]. A group of at least ten people developed the Modulor, but eventually, Le Corbusier patented it for himself. When narrating the registration procedure in the patent office, he admits that he does not know how to explain it [13:42].

It is an approximations system according to Suárez (2009), the exact values obtained by the harmonic division were rounded to adjust the model [14]. This Le Corbusier's stylized drawing represents an unreal body [15]. In contrast to Ernst Neufert's Bauentwurfslehre, published in 1936 that described the construction of reality literally to the millimeter, the Modulor presents idealized measures of how its author thought they should be [16].

Although the Modulor continues to be considered an icon of human proportion and an anthropometric manual, this essay contributes to the criticism and questioning of its content. Mainly anthropometric qualities that have been attributed to the model but that it does not have, a situation masked by drawings with a golden section that attracts attention as distractors. Rather, the Modulor is an anthropometric myth starting with established human heights.

Then the starting point is the stature. Series of human heights registered over time in France and European countries are contrasted with the proposals of that model, to answer questions such as What are the Modulor's anthropometric foundations to consider it a human scale? What dimensional ranges of the population does the model cover? How appropriate is it to be considered "a system to harmonize all the productions of the world"?

\section{Materials and Methods}

Documentary research on different anthropometric databases, some French and from other countries; previous and specific to the Le Corbusier time. Modulor measurements and anthropometric human stature and width databases were contrasted.

\section{Results: Anthropometry Effect on the Height of the Humanoid with the Raised Arm}

Le Corbusier observed in folk architecture as well as in highly intellectual one, the constancy of 2.10 to 2.20 meters ( 7 to 8 feet) between the floor and ceiling. He assumed this measurement corresponded to that of a man with his arm raised, therefore a human scale [13:26]. In his quest to find the cornerstone of his hypothesis, he first considered 1.75 meters as the average height of the French citizen, without any basis in anthropometric statistics.

Thus began a long process to frame a non-human, rather humanoid figure of standard height with the arm raised, without proportional analysis between real body parts, with regulatory lines generated from squares and a right angle.

Le Corbusier described himself as a visual [13: 27] and graphic [13:75] reasoner. So, he generated a visual tool to solve the dimensional problem in design: to reconcile the Anglo-Saxon metric system and the decimal metric system [13: 17]. Also, impose it as the harmonizing system of the productions flow throughout the world [13: 101].

For years Le Corbusier delegated to collaborators to develop a model appropriate to his intuited figure, among which were: Gérald Hanning, Elisa Maillard, André Wogenscky, Jerzy Soltan, Roger Aujame, Hervé de Looze, Jean Préveral, Marcel Py, André Maisonnier and Justino Serralta [17]. They failed to adjust the humanoid measurements with Le Corbusier's pre-established scheme. Finally, the young Py recommended to change data from 1.75 meters to 1.83 meters, taking as an example the handsome six feet tall detectives from English crime novels [13: 53].

The new measure conforms to the assumption of Le Corbusier, who justifies it assuming the criterion that everything fits in big. Thus, he would have continents usable for all breeds' statures [13: 59].

With this idea, he assumes that all body parts are average measures in proportion to height, and being a large standard, the Modulor is suitable for everyone. This wrong criterion for the design of architectural spaces, given the dimensional variability of the population, shows that Le Corbusier assumed both dimensions of height for convenience, discarding the vast field of study that makes France a pioneer in anthropometry.

That is, the first impression of the Modulor is of a human scale useful for design. Although many architects have accepted it with admiration, that stature would have to be confirmed, with french and other countries' anthropometric data, if intended to be the measure for all usable things.

Anthropometry, the measure of man, from the Greek words Anthropos and métron, is a science that followed different paths over time. The application fields are varied. Just as most designers may not be familiar with anthropometric work in the sciences, scientists may not be familiar with ergonomic anthropometry [18]. 
However, a responsible interest must have induced the author of the Modulor to base what intuition glimpsed, especially since he lived where there is vast experience in human height measurements for centuries, such as France. The Modulor's generating approach is eminently non-anthropometric since height is a variable datum, non-standard as Le Corbusier determined. This topic requires anthropometric considerations regarding the Modulor's key measure, the stature, prior raised arm.

Anthropometry is part of physical anthropology and is studied considering physical, biological, and environmental variables [19]. Average height is a net nutrition level index or even an index of chronic malnutrition [20]. The adults' average height summarizes the nutritional intake and energy expenditure during twenty years of the growth period [19].

Other human height change factors are the improvement of environmental conditions, nutrition, acceleration of the growth of puberty, social, economic, and working conditions, medical and genetic factors, and urbanization degree as well [21-24].

Individual human height refers to the genetic potential expression randomly distributed within a given population [19]. Also, it's determined by social factors between groups and can vary over time [25].

Such variability is so significant due to the inherent human-object-space metric interaction that workspace design should not be conceived as a one-dimensional problem. There is not enough trend in any of the proportions or dimensional body relationships, which can be associated with different population sizes [26].

Ergonomically, determining fixed harmonious proportions is paradoxical given the great size variability observed in population groups [12]. No one has average full-body measurements, but only a few people have average dimensions between each other in body segments [27]. Let's see real data not contemplated by Le Corbusier.

France, a pioneer country in anthropometric research, registers many references. French physical anthropology goes back to the first works of Volney (1757-1820) although the first anthropometric study carried out on stature was due to Count Guéneau de Montbeillard (1720-1785) in 1759, to Jacques Tenon (1724-1816) in 1783 and Antoine-Audet d'Hargenvilliers (1768-1835) [25].

In anthropometry, height is not estimated as an immutable measure. For example, for Alphonse Bertillon, the body proportions of any person are different, so he developed a way of using photographs to measure a person's unique dimensions [28]. The Bertillon system, which was one of the first anthropometric procedures disseminated, arrived in the United States in 1892, and by 1985 had been incorporated in Latin American countries [29].

The physical anthropology of France began between 1780 and 1830. Two interpretations coexisted in the middle of the 19th century, one social (L. Villermé, A. Quetelet) and the other racial (P. Broca, J. C. M. Boudin, J. Bertillon) [30].

Reference works such as the Dictionnaire Encyclopédique des Sciences Médicales (since 1879) collect their own measuring terms: accroissement (increase), croissance (growth), taille (size), and the mécomètre (proportional compass) were diffused [31].

Experience, specialization, research, and organizations identify the field of anthropometric knowledge in France. An anthropometric tradition in which to support proposals related to the dimensions of man, such as stature.

Comparing data provided by the Statistical Yearbook of France, between 1880 and 1960, the average calculated for all French regions increased from $165.3 \mathrm{~cm}$ to $169.9 \mathrm{~cm}$ [22]. Table 1 shows percentages corresponding to small, medium, and large heights between 1920 and 1960. During the time Le Corbusier developed his work, the height average of 1.60-1.69 had higher percentages. The stature's initial proposal of 1.75 was noticed until 1960 but is not a higher percentage (15.4\%). The height defined by assistant Py, of 1.83, fitted to a population small percentage (5.4\%).

Starting in 1960, height continued to increase in France. It is estimated that the increase accelerated, from $0.3 \mathrm{~cm}$ every 10 years at the beginning of the century, from $1 \mathrm{~cm}$ in the middle of the century, reaching $1.7 \mathrm{~cm}$ per decade. Being since 1974 an average of $172.33 \mathrm{~cm}$ [32] and 173.86 cm., in 1979 [33].

In the period 1970-80, the increase in the French population stature points out a maximum, from then on it continued to increase, leading to an average height of 175, 8 cm until the year 2000 [34].

Stature varies over time, as do body segments dimensions, a condition not considered by Le Corbusier's group. The initial mean height, $175 \mathrm{~cm}$, could be reached mainly in France until the 20th century's end.

In the European context, throughout time and Le Corbusier's lifespan, in no country did the height reach the dimension of $1.83 \mathrm{~m}$. See Table 2. 
Table 1. Percentages of heights between 1920 and 1960 in France. Adapted from [22]

\begin{tabular}{|c|c|c|c|c|c|c|c|}
\hline \multirow[b]{2}{*}{ Year/cm } & \multicolumn{2}{|c|}{ Small heights } & \multicolumn{2}{|c|}{ Medium heights } & \multicolumn{3}{|c|}{ Large heights } \\
\hline & $x-1.54$ & $1.55-1.59$ & $1.60-1.64$ & $1.65-1.69$ & $1.70-1.74$ & $1.75-1.79$ & $1.80-\mathrm{x}$ \\
\hline \multirow[t]{2}{*}{1920} & 3.9 & 12.6 & 28.2 & 29.9 & 17.9 & 5.6 & 1.2 \\
\hline & \multicolumn{2}{|c|}{$16.5 \%$} & \multicolumn{2}{|c|}{$58.1 \%$} & \multicolumn{3}{|c|}{$24.7 \%$} \\
\hline \multirow[t]{2}{*}{1930} & 1.9 & 7.9 & 23.7 & 32.1 & 23.2 & 8.4 & 2.1 \\
\hline & \multicolumn{2}{|c|}{$9.8 \%$} & \multicolumn{2}{|c|}{$55.8 \%$} & \multicolumn{3}{|c|}{$33.7 \%$} \\
\hline \multirow[t]{2}{*}{1940} & 1.4 & 5.9 & 20.1 & 30.7 & 26.4 & 11.3 & 3.5 \\
\hline & \multicolumn{2}{|c|}{$7.3 \%$} & \multicolumn{2}{|c|}{$50.8 \%$} & \multicolumn{3}{|c|}{$41.2 \%$} \\
\hline \multirow[t]{2}{*}{1950} & 1.6 & 7.0 & 19.9 & 30.7 & 26 & 10.9 & 3.3 \\
\hline & \multicolumn{2}{|c|}{$8.6 \%$} & \multicolumn{2}{|c|}{$50.6 \%$} & \multicolumn{3}{|c|}{$40.2 \%$} \\
\hline \multirow[t]{2}{*}{1960} & 0.8 & 4.2 & 15.4 & 28.6 & 29.6 & 15.4 & 5.4 \\
\hline & \multicolumn{2}{|c|}{$5.0 \%$} & \multicolumn{2}{|c|}{$44.0 \%$} & \multicolumn{3}{|c|}{$50.4 \%$} \\
\hline
\end{tabular}

Table 2. Height variations in Europe. Adapted from [22, 33].

\begin{tabular}{|c|c|c|c|c|c|c|}
\hline & Century XIX & Height cm & Century XX & Height cm & Century XX & Height cm \\
\hline Spain & $1860-1893$ & 163.7 & 1955 & 166.1 & $1960-1980$ & 171.3 \\
\hline Portugal & 1899 & 163.4 & 1932 & 165.3 & 1980 & 167.1 \\
\hline Italy & 1880 & 162.8 & 1952 & 167.4 & $1960-1977$ & 172.19 \\
\hline Switzerland & 1884 & 163.5 & 1957 & 172.1 & $1962-1977$ & 175.5 \\
\hline West Germany & 1887 & 165.2 & 1958 & 173.5 & $1960-1978$ & 178.0 \\
\hline Belgium & 1880 & 165.5 & 1953 & 171.7 & $1960-1979$ & 175.3 \\
\hline Netherlands & 1877 & 165.2 & 1960 & 176 & $1960-1978$ & 180.3 \\
\hline Denmark & 1879 & 167.7 & 1960 & 175.4 & $1960-1980$ & 179.8 \\
\hline Norway & 1880 & 169 & 1960 & 177.1 & $1960-1980$ & 179.5 \\
\hline Sweden & 1880 & 168.6 & 1961 & 177 & $1960-1979$ & 179.17 \\
\hline Great Britain & 1881 & 172.6 & 1951 & 173 & & - \\
\hline
\end{tabular}

In 2019 the mean height of 19-year-olds in the Netherlands was 183.8 centimeters [35].

In the Dinaric Alps region, which includes Croatia, Serbia, Bosnia, and Montenegro, most mean heights reach 185.5 in addition to cases with $190 \mathrm{~cm}$ (28\%), 195 (5\%), and $200 \mathrm{~cm}$ (2.5\%) [37]. The Modulor would also be useless for these populations, as the population would have outgrown the humanoid figure.

Stature dimensional contrasts are also noted between other populations globally, by wide samples.

In 1996 Dutchmen were the tallest people on the planet at $182.5 \mathrm{~cm}$ average stature (180.6-184.5). The gap with the lower countries (Timor-Leste, Yemen, and Laos, where men are $\sim 160 \mathrm{~cm}$ tall) is 22 to $23 \mathrm{~cm}$. The tallest women lived in Latvia, the Netherlands, Estonia, and the Czech Republic, with a mean height exceeding $168 \mathrm{~cm}$, creating a global gap of $20 \mathrm{~cm}$ in the height of the shortest women located in Guatemala, with an average height of $149.4 \mathrm{~cm}$ (148.0-150.8) [37, 38].

The Modulor cannot be a human scale model when compared to differences in height. By a standard measure based on a fixed mean dimension, the requirements of people with a diversity of metric characteristics are not satisfied.

\section{Discussion}

In this anthropometric context can be idly speculated why Le Corbusier did not consider the stature variants. The Modulor has no anthropometric fundamentals, rather seems whimsical justification fitting human scale and floor-to-ceiling distance. Also forced a humanoid schematic entangled in golden section interpretations as a dimensional base, pretending to establish an unreal stature as the cornerstone of product sizing in the world.

Le Corbusier had recognized the dimensional difference among Vikings and Phoenicians [13: 19] but determines that the humanoid with the raised arm is a proportional standard for all things, therefore, including the Nordic and Asian populations. Although his author intended it to be so, it is impossible to fit population dimensional variability to 
fixed metric standard.

His lack of anthropometric criteria is demonstrated through the books that describe the model. For example, he says that the human eye is located at an average height of 1.60 meters from the ground [13: 70]. This equates to a height between 1.71 and 1.72, by the difference in distances from floor to line of sight and the measurement from the floor to top on the head (vertex), of approximately 12 centimeters. That is a discordant measure with 1.75 and 1.83 .

Le Corbusier determines his proposal from two squares and a right angle [13: 35]. Sometimes with sketches, others incorporate the figure inside squares framing the humanoid. But the dimensional relationship does not fit with the different widths of a real human scale.

For example, the metric correspondence between shoulder width and the side of the square is not appreciated. Refer lateral dimensions in railway wagons cabins and human representations with body width metric assignments [13: 195]. By the way, very similar to that proposed by Neufert [2: 27, 28), but Le Corbusier dedicates a few words to them in three lines without transferring them to the model.

In addition, the sitting posture was also not studied anthropometrically at all. In the Modulor posture diagrams there are five standing measurements $(2.26,1.83,1.40,1.13$, 0.86 meter), and three seated $(0.70,0.43,0.27$ meter). All dimensions vertically, none considering body widths [13: 62].

Table 3 shows specific, extreme, and average anthropometric measures of a sample of 6,672 both sexes people, aged 18 to 79 , results of an investigation from October 1959 to December 1962 [39]. Two Modulor's dimensions are compared with sitting postures measures, the popliteal height, and the height at the elbow in a seated posture. Those established by Le Corbusier when contrasted, people would be left with their feet dangling when sitting (1st percentile) or with high armrest height (1st percentile). In other postures, the Modulor is not suitable either.

In the Modulor, the dimensional assignments for such postures are not necessarily anthropometric data but arithmetic as a product of segmenting a humanoid figure.

Although the Modulor was never applied in the automotive field, Le Corbusier tried with his Voiture
Minimum in 1928 [40] to propose a minimum vehicle, but with a whole series of issues such as a very architectural, two-dimensional design, without technical nor mechanical details [41]. Measuring 3.75 meters long, 1.85 meters wide, and approximately 1.85 meters high, it was configured combining circle and rectangle segments and the golden section [42]. The cabin interior width dimension is not enough for three large people, 95th percentile, with a height of 1.78 and shoulder width of 0.62 [43: 98, 100], comfortably seated in the front seat.

In his essay, Le Corbusier recounted his experience on transport during tours of India in 1951. The pockets are emptied due his knees were higher than his pelvis. There is no use being vigilant. He felt like Modulor abandoned him [44: 32]. That type of vehicle was manufactured to appropriate metric standards for the target population segment: recruits within an anthropometric range suitable for the production economy. If the Modulor had been accepted as these vehicles' manufacture standard, based on persons with 1.83 height measure, the jeep driver's feet wouldn't have reached the pedals.

The height of the humanoid does not establish whether it is with or without shoes. They are important data due to the functional anthropometric variability [43]. In some cases, the height of the shoe's heel and its variations in use, by age and sex, impact the vertical reach, for example.

Anyway, with a functional vertical reach of 2.19 (95th percentile) and a height of 1.855 (95th percentile), adults aged 19-65 [4] do not correspond with Modulor dimensions, 1.83-2.26.

Anthropometric measurements are made with the least amount of clothing on the subject or naked. This is necessary regarding the information on the development and growth of individuals or nutritional status. Other anthropometric applications require a dressed subject, as in everyday life and in the workplace, where culturally is the way people perform. In some types of objects, the design related to the attire such as suits, dresses, shirts, pants, footwear, the slack factor is added to the basic dimensions due to the need for adjustment due to body movements.

In tools' design, detailed anthropometric data such as hands, wrists, fingers, arm, forearm, legs, foot, ankle, for better and healthier performance, which the Modulor lacks.

Table 3. Measurements of height and sitting posture. Adapted from anthropometric sample [39] and [13]

\begin{tabular}{|c|c|c|c|c|c|}
\hline & Gender & p99 & p1 & $\mathbf{m}$ & Modulor \\
\hline \multirow{2}{*}{ Height } & M & 189.48 & 156.781 & 173.22 & \multirow{2}{*}{1.83} \\
\hline & W & 174.75 & 145.03 & 160 & \\
\hline \multirow{2}{*}{ Popliteal height } & M & 50.8 & 37.84 & 43.94 & \multirow{2}{*}{43} \\
\hline & W & 45.72 & 33.27 & 39.62 & \\
\hline \multirow{2}{*}{ Height to elbow in sitting posture } & M & 82.55 & 53.84 & 68.07 & \multirow{2}{*}{70} \\
\hline & W & 75.94 & 48.76 & 62.73 & \\
\hline
\end{tabular}


The Modulor was male gender-focused [15]. Women body was belatedly considered but finally rejected as a proportional measures source. In the Modulor 2 book, it is mentioned that one of the collaborators, Justino Serralta, introduces a 1.83 height female humanoid in the system [45: 50], that would be like fitting an older adult or a child humanoid figure with the same height as the 1.83 height model. The Modulor is a metric model that excludes women, children, the elderly, people with disabilities, and other persons [12, 44]. So, because Le Corbusier's height is said to be 1.73 meters or five feet eight inches, neither would the model apply to him [46].

On the other hand, the Modulor is a one-dimensional humanoid. Human activities take place in space, so interactions among people and objects encompass relationships in three dimensions. The three reference planes in anthropometry, sagittal, frontal, and horizontal, place the body dispositions in an interface.

The Modulor is a golden section linear series fragment in a range from zero to infinity [13: 45]. For this reason, Le Corbusier decides to implement it as a roll-up tape inside an aluminum box.

This contradicts the theoretical approach proposed by Le Corbusier, insofar as volume and surface are the elements through which architecture manifests itself [47: 17].

Lacking three-dimensional qualities, the stature, the navel height, and the hand height with the raised arm, are trapped in one dimension.

When taking this data to accommodate distances, the measurement from floor to navel is not necessarily adequate for spatial requirements in different postures of different people, considering that the human being occupies three-dimensional space.

Le Corbusier standardizes a space based on the humanoid measure of the raised arm as a container of life. Segments of that vertical distance are used to size rooms and furniture that occupy three-dimensional space (44: 197). In his personal case, it might be appropriate to size $(2.26 \times 2.26+33)$ the Petit Atelier (Paris, 1950) and the furniture space (1.13 x 53) [17]. Assume that the measure is adequate for all designers, would require a specific anthropometric validation.

It is not usual for architects to generate people-size-fitted proposals, like clothes. However, professionals have reviewed human scale metric diagrams in user-object interaction. This exercise seeks to sensitize the designer regarding measurements and proportions. The problem arises when it is subjected to a standardization and generates non-valued, disergonomic and dehumanized prototypes. That situation shows an unprofessional attitude that impacts people lives, who do not have standardized needs.

Two significant anthropometric aspects are body segments denominations and the measurement units.

This model was intended to be the-all-things-measure, to replace the decimal metric system and the English measurement system. As a new proportional metric system, how would its segments and magnitudes be denominated?

For example, what is the height from floor to navel called on the Modulor? It is called 1.13 meters, or it can also be called 44.5 inches. A suggested nomination would be nombril d'or (golden navel), to distinguish it from the series of decimal and English measurements. Neither is stature, which could have been nominated as a taille d'or. Only the humanoid Modulor, which is known as the distance from the ground to the tip of the raised arm, is only identified by describing it.

In ancient Mexico, among the variety of anthropometric dimensions considered to be applied in daily activities is the so-called Maitl-Neuitzantli, known as indigenous vertical breaststroke, highly variable, applied to the land for cultivation. It corresponds to the man's stature, ranging from the left foot to the raised right hand. Also the Cenmaitl, length between finger to finger with the arms extended or the Cenmacolli, measured from the shoulder to the tip of the longest toe [14].

An alternative nomination for Modulor, not only on planet earth but applicable in the universe, was the one invented by Jean Dayre, from the Secretary of State for the Economy, in Paris. In 1951 he established units based on golden logarithms or logors, which he called almegans. Arguing that since the stature is of a truly large man for his size, he called him a megalontrope [44: 69]. So, both Dayre and Le Corbusier set measurements from drops of water to beyond the Milky Way, in another megalomaniac effort to justify the Modulor as a measure of all things.

Le Corbusier criticized the unit of measurement of the decimal system, the meter, arguing is not related to human proportions. However, he presents the Modulor with the English and the decimal metric systems' measurements.

He applied such a model in architecture by adopting in any part of his modular scale meters and inches as units. In the pioneering complex, the Housing Unit in Marseille, the author describes the building dimensions as 140 meters long, 24 meters wide, and 56 meters high [13: 102]. From there, he lists other dimensions, taking care not to mention much to the meter or inches, but a few acronyms next to it that refer to the red series or the blue series. Thus, he determined the measurements of the construction first stone: Width 86 - B.s. (blue series) Height 86 - B.s. (blue series) Lenght 183 - R.s. (Red series) [13: 130].

Describing the urban complex of Chandigarh, he uses meters, that unit of measure against which he tried to contrast his Modulor. In this regard, he mentions that the first stage comprises 17 sectors of $800 \times 1200$ meters per side [44: 214]. The Modulor, without defining its own specific metric units, was subjected to the meter and the inch.

Le Corbusier's visual reasoning was limited in the Modulor to a linear magnitude. The decimal metric 
system and English metric system encompass the length and mass, capacity, volume, along with submultiples.

The Modulor's dimensions are imaginary ones, not anthropometric, unrelated to other bodies measures, such as arms and legs lengths, shoulder widths, perimeters, diameters, reaches and clearances, weight, and complexion.

\section{Conclusions}

The Modulor should not be a human scale model compared to differences in real human measures. It is an imaginary standard measure, which does not satisfy real population variable dimensional requirements.

Due to the world population stature is variable, the Modulor's standard is very limited, only suitable for a small range of height measurements. Modulor assigned dimension, 1.83 meters, in the population of many countries has not yet been reached, and in other places, it has been exceeded. Therefore, the Modulor is not globally anthropometric.

The Modulor, in addition, is not inclusive when it comes to different people and genders but would be exclusive for the male population. Given the null reference to real body measurements and their parts, it is not valid as a human scale.

One way to better understand this is to analyze the components of the initial Modulor separately before it has been transformed into the tape. The figure of the humanoid, on the one hand, and the golden lines on the other.

The second is common linear geometric games in the basic procedures for exercising traces in the golden section. Le Corbusier spent a lot of time and effort on golden section geometric drawings, without anatomical relationships but drawing attention away from anthropometric limitations.

Reviewing its components separately stands out the humanoid figure fallacy as a human scale since the vertical dimensions are an abstract correlation with just one data, 1.83. Likewise, the segments lack the system's own nomination, which submits the model to the meter and the inch.

The proportions derived from a human scale with the arm raised do not necessarily correspond to those where reach or clearance are fundamental in human activities, neither standing nor sitting.

The measurements set by Le Corbusier would be adequate in spaces for identical mannequins but not for human beings. People's measurements are varied. He did not understand it that way, possibly because he did not resort to the vast collection of anthropometry information that France and other countries have, nor do those who currently hold that model on the podium of human-scale proportions in architecture.
The Modulor is an anthropometric myth, but it can be useful as a learning tool, as an example of erroneous criteria of human-scale design.

It is recommended to stop including it as an anthropometric manual and human proportion system. Interested designers can consult other anthropometric databases to confirm the Modulor fallacy.

\section{Authors' Contribution}

YA participated with second read of the manuscript. CF participated in format sequence and second read of the manuscript. JL conceived the study, content curator, participated in its design and drafted the manuscript.

\section{REFERENCES}

[1] Zeising, A., “Aesthetische Forschungen”, Frankfurt a. M.: Meidinger Sohn und Comp. Germany, 1855. Cited in Ghyka, M., Aesthetics of Proportions in Nature and in the Arts, Poseidón, pp 38, 39, 1953.

[2] Neufert, E., "Its Elements of Construction Projects", 7th French edition, French translation, and adaptation of the 33rd edition of the work published in German under the title: Bauentwurfslehre, Dunod, 1966.

[3] Panero, J., Zelnik, M., "Human dimensions in interior spaces”, Gustavo Gili, 1983.

[4] Pheasant, S., "Bodyspace. Antropomety, ergonomics and the design of work”, Taylor \& Francis, 1992.

[5] J. A. Roebuck Jr, J. A., “Anthropometric Methods: Designing to Fit the Human Body”, Santa Monica: Human Factors and Ergonomics Society, 1993.

[6] Tilley, A. R, Dreyfuss, H., Associates, "The measure of man and woman. Human factors in design”, John Wiley \& Sons, Inc., 2002.

[7] Boueri, J., "Design and Dimensioning of Housing Spaces. Activities Space”, Letters and Colors Station, 2008.

[8] Kuroishi, I., "Mathematics for/from Society: The Role of the Module in Modernizing Japanese Architectural Production”, Nexus Network Journal - Vol. 11, No. 2, 2009.

[9] Salinas F., O., “Technology and Design in Pre-Hispanic Mexico", Faculty of Architecture, Industrial Design Research Center, National Autonomous University of Mexico, 1995.

[10] UNESCO, “The architectural work of Le Corbusier an outstanding contribution to the Modern Movement inscribed on the UNESCO World Heritage list”, United Nations Educational Scientific and Cultural Organization, World Heritage Convention, 2016. https://lecorbusier-worl dheritage.org/en/ 
[11] Bustamante, A., "Ergonomics, anthropometry and indeterminacy”, Psychology Yearbook 2004, vol. 35, n. 2, 439-460, 2004.

[12] Ranger, F., "Evaluation of the Anthropometric Offer for Product Design", Thesis presented as Partial requirement of the Master in Biology, University of Quebec In Montreal, Library Service, 2010.

[13] Le Corbusier, “The Modulor. Essay on a harmonic measure on the human scale universally applicable to architecture and mechanics”, Poseidón, $2^{\text {nd }}$ Edition, 1953.

[14] Suárez J., C. M., "Metrics in architecture”, Ibeoamerican University. Library Francisco Xavier Clavijero, 2009.

[15] Lambert, L., "A subversive approach to the ideal normatized body”, The Funambulist Review. Architectural Theories, 2012.https://thefunambulist.net/architectural-pro jects/architectural-theories-a-subversive-approach-to-the-id eal-normatized-body,

[16] Hernández G., A., "The measure of all things”, Arquine, 2016.https://www.arquine.com/la-medida-de-todas-las-cos as/

[17] Cohen, J. L., "Le Corbusier's Modulor and the Debate on Proportion in France”, Architectural Histories, 2(1): 23, pp. 1-14, 2014. DOI: http://dx.doi.org/10.5334/ah.by

[18] Norton, K., T. Olds, T., “Antropometrica”, BIOSYSTEM, Educative Service, 1995.

[19] Heyberger, L., "The evolution of living standards in France, from the end of the Ancient Régime to World War II, Anthropometric approach”, Ruralia, 2005. http://journals.openedition.org/ruralia/1090

[20] OMS, “Technical Report Series, No. 854, Use and Interpretation of Anthropometry, Report of a WHO Expert Committee”, Geneva, 1995. World Health Organization, 2005. https://www.who.int/childgrowth/publications/physi cal_status_fr/en/

[21] Guyot-Daubés, M., "Variations in Human Stature, Popular Science Monthly”, Volume 31 July 1887. https://en.wikisource.org/wiki/Popular_Science_Monthly/ Volume_31/July_1887/Variations_in_Human_Stature 1887.

[22] Chamla, M. C., "The increase in stature in France from 1880 to 1960; comparison with the countries of Western Europe, In: Bulletins et Mémoires de la Société d 'Anthropologie de Paris, XI ${ }^{\circ}$ Série. Volume 6 booklet 2, 1964. pp. 201-278, 1964. DOI: https://doi.org/10.3406/bms ap.1964.1275

[23] Komlos, J., "On the importance of anthropometric history", In: Annales de démographie historique, Kinship networks. pp. 211-223, 1995. DOI: https://doi.org/10.3406/adh.1995. 1899

[24] Prado L., L. R., Ávila Ch., R., E., Herrera L., E., “Anthropometry. Ergonomic factors in design”, University of Guadalajara, University Center of Art, Architecture and Design. Ergonomics Research Center, 2005.

[25] Heyberger, L., "The revolution of bodies. Decrease and growth in stature of inhabitants of towns and countryside in France, 1780-1940 Strasbourg”, Presses universitaries de Strasbourg, Multimedia editorial department of the
University of Technology of Belfort-Montebéliard (UTBM), 2005.

[26] Haslegrave, C. M., "Characterizing the anthropometric extremes of the population”, Ergonomics, 29:2, 281-301, 1986.

[27] Behara, D. N., Das, B., "Structural anthropometric measurements of the Canadian adult population: the fallacy of the 'average person' concept”, Theoretical Issues in Ergonomics Science, 13:3, 380-392, 2012.

[28] Bertillon, A., "Forensic Photography, with an appendix on anthropometric classification and identification, Gauthier-Villars and Sons, Interuniversity health library (Paris), Internet Archive Python library 1.7.4, 1890.

[29] Villegas, K., "Criminological theories, and the arrival of the Bertillon system in Mexico City, a case of success? National Autonomous University of Mexico, Historical Letters, Number 13, Fall 2015-winter 2016, pp. 87-110 / ISSN: 2007-1140, México, 2016.

[30] Martínez C., J. M., Puche G., J., “The Evolution of Height in France and Spain, 1770-2000. Historiographic balance and new evidence”, Dynamis 2011; 31 (2): 429-452, 2011. DOI:10.4321/S0211-95362011000200009

[31] Ballester A., R., Perdiguero G., E, "Science and ideology in human growth studies in France and Spain (1900-1950)", Dynamis. 2003; 23; 61-84., 2003. https://www.ugr.es/ dynamis/completo23/PDF/Dyna4.pdf

[32] Olivier G., Chamla M-C., Devigne G., Jacquard A., “The growth of stature in France: I. The acceleration of the phenomenon", In: Bulletins and Memoirs of the Anthropological Society of Paris, XIII ${ }^{\circ}$ Series. Volume 4 booklet 3, pp. 197-204, 1977. DOI: https://doi.org/10.3406/bmsap.1977.1875

[33] Chamla, M. C., The recent evolution of stature in Western Europe (Period 1960-1980). In: Bulletins and Memoirs of the Anthropological Society of Paris, XIII ○ Series, Volume 10 issue 2, pp. 195-224, 1983 DOI: https://doi.org/10.3406/bmsap.1983.3895

[34] Pineau, J. C., "The stature in France for a century: general and regional evolution”, In: Bulletins et Mémoires de la Société d'anthropologie de Paris, New Serie. Volume 5 booklet 1-2, pp. 257-268, 1993. DOI: https://doi.org/10.3406/bmsap.1993.235

[35] NCD-RisC, "Height and body-mass index trajectories of school-aged children and adolescents from 1985 to 2019 in 200 countries and territories: a pooled analysis of 2181 population-based studies with 65 million participants.”, Lancet 2020; 396: 1511-24, 2020.

[36] Pineau, J. C., Delamarche, P., Bozinovic, S., "The Dinaric Alps: a people of great size”, C. R. Biologies 328, 841846, 2005. DOI: 10.1016/j.crvi.2005.07.004

[37] NCD-RisC, “A century of trends in adult human height. NCD Risk Factor Collaboration, eLife 2016;5:e13410. DOI: 10.7554/eLife.13410, 2016.

[38] Roser, M., Appel, C., Ritchie, H., "Human Height”, Published online at OurWorldInData.org., 2020. https://ourworldindata.org/human-height

[39] National Center for Health Statistics NCHS "Weight, 
Height, and Selected Body Dimensions of Adults United States 1960-1962", National Health Survey, Series 11 Number 8. Scientific and Technical Information Branch National Center for Health Statistics Public Health Service, HRA, 1965. https://www.cdc.gov/nchs/data/series/sr_11/sr 11_008.pdf

[40] Schnoor, C., "Review of: Antonio Amado: Voiture Minimum. Le Corbusier and the Automobile", Architectural Histories, 1(1): 8, pp. 1-2, 2013. DOI: http://dx.doi.org/10.5334/ah.a

[41] Margolius, L., “Automobiles by Architects.”, Chichester: John Wiley and Sons. En Schnoor, 2013. Review of: Antonio Amado: Voiture Minimum. Le Corbusier and the Automobile, Architectural Histories, 1(1): 8, pp. 1-2, 2000. DOI: http://dx.doi.org/10.5334/ah.a

[42] Smith, K., "Concept car of the week: Le Corbusier's Voiture Minimum (1936)”, CDN Car Design News, 2015 https://www.cardesignnews.com/concept-car-of-the-week/ concept-car-of-the-week-le-corbusiers-voiture-minimum-1 936/24910.article

[43] Ávila, R., Prado, L., González, E., “Anthropometric dimensions of the Latin American population”, University of Guadalajara, University Center of Art, Architecture and Design, 2007.

[44] Le Corbusier. "Modulor 2 1955. Users have the word, (Continuation of The Modulor 1948)”, Poseidón, 1962.

[45] Barrera, A., "Modulor II, a reflection from art on exclusion and architecture. Interview with Nina Fiocco", 2016. https://ladobe.com.mx/2016/10/modulor-ii-una-reflexion-d esde-el-arte-sobre-exclusion-y-arquitectura/

[46] Dimensions. "Le Corbusier Dimensions \& Draws", Dimensions. Com., 2021.https://www.dimensions.com/ele ment/le-corbusier

[47] Le Corbusier, “Towards an architecture”, Apóstrofe. Poseidón, Reprint 1958, $2^{a}$ reprint, 1998. 